\title{
Onuoha Kalu $v$ The State and flaws in Nigeria's death penalty jurisprudence
}

\author{
Oluwatoyin Badejogbin* \\ Research Associate, Centre for Comparative Law in Africa, University of Cape \\ Town, South Africa
}

\begin{abstract}
Summary
In Onuoha Kalu v The State, the Supreme Court of Nigeria affirmed that the death penalty violated neither the right to life nor human dignity under the Nigerian Constitution. Since the decision, the list of capital crimes has grown in Nigeria. In the last decade and more, not less than eight Nigerian states made kidnapping a capital offence, while 12 others adopted Shari'a criminal codes that extend capital punishment to sexual offences. Although executions have been rare, courts have continued to impose the mandatory death penalty, swelling the number of inmates on death row. These developments are unconstitutional and exploit two shortcomings: First, the Constitution's provision on penalties that violate human dignity - or the interpretation of the provision - is tenuous. Second, Nigerian courts have surrendered their autonomy to statutory prescripts that remove discretion from sentencing. The Kalu case is one of many decisions that expound a flawed death penalty jurisprudence in Nigeria. A review of the jurisprudence indeed is overdue. While the death penalty may be constitutional under Nigerian law, the basis of imposing the sentence in most cases is constitutionally flawed.
\end{abstract}

Key words: death penalty; penal proportionality; right to human dignity; right to life

* PhD (Cape Town); tbadejog@hotmail.com 


\section{Introduction}

Onuoha Kalu $v$ The State ${ }^{1}$ is one of many judicial pronouncements that affirm the constitutionality of the death penalty in Nigeria. It no doubt is Nigeria's locus classicus on the subject. The appellant had appealed a death sentence that was imposed under section 319(1) of the Criminal Code of Lagos State in South-West Nigeria, ${ }^{2}$ contending that the penalty contravened sections $30(1)$ and $31(1)$ of the Constitution, ${ }^{3}$ which guarantee the rights to life and human dignity. Section 319(1) of the Criminal Code prescribes the death penalty for murder. The appellant argued that the penalty and its execution violated constitutional guarantees of life and human dignity.

The appeal potentially had watershed significance. Had it succeeded, a litany of Nigerian statutes that prescribe the death penalty for sundry offences would have been annulled. Prior to the appeal, debates had raged about the constitutionality of the penalty in Nigeria. It had become an issue of significant public interest, which the Kalu appeal was intended to resolve. The appeal's significance was not lost on the bench and bar in Nigeria. The latter weighed in with various positions that were supported by copious references to foreign jurisprudence, for which the Supreme Court of Nigeria was amply grateful.

The outcome, however, was hardly what the appellant wanted. Having applied its mind to relevant constitutional provisions and comparative jurisprudence, the Supreme Court concluded that the penalty violated neither the right to life nor human dignity as the Nigerian Constitution allowed the penalty. Although the decision became a locus classicus, it hardly puts the matter to rest as it was meant to. Kalu provides far less clarity on the subject than it was presumed to do. The Supreme Court's interpretation of the human dignity provision in the Nigerian Constitution could have been more insightful, and its engagement with comparative constitutional sources more discreet. Had the Court applied more rigour, it would have spotted textual transitions in constitutional provisions on human dignity in Nigeria, which left the human dignity clause fundamentally different from comparative human dignity clauses that it consulted in other national constitutions. Overlooking textual differences led the Court to misread how those clauses have been interpreted.

The Supreme Court's failure to recognise and weigh the probable consequences of textual differences makes Kalu a poor precedent for whether or when the death penalty violates the Constitution. However, the Court was hardly alone in this error: The parties apparently did not bring the differences and their implications to the Court's attention. This leaves wide open the question about the

[1998] 13 NWLR 531.

Cap 31, Laws of Lagos State of Nigeria, 1973.

Constitution of the Federal Republic of Nigeria, 1979. 
constitutionality of punishments that infringe human dignity in Nigeria. The article interrogates the question, starting with a brief outline of Kalu's legacy.

Before commencing the interrogation, however, it is necessary to delimit the scope of the article. The article seeks to contribute to developing the jurisprudence on the constitutionality of the death penalty in Nigeria, and to illustrate what needs to be reviewed to ensure compliance with international human rights standards that have been set for countries that have not abolished the penalty. Thus, much of the article focuses on the decisions of the Nigerian Supreme Court. While the article recognises that judicial decisions may sometimes reflect prevailing ideological or sociological leanings in a society, Nigerian courts, in their conservative tradition, adopt a literalist approach to interpreting death penalty prescripts. This has left little room for non-legal influences on their decisions to impose the death penalty. Even when the Nigerian Supreme Court had the opportunity in Kalu and Joseph Amoshima $v$ The State 4 to interrogate the constitutionality of the death penalty in an evolving socio-legal context, its conservatism caused it to resist being persuaded to go with global trends that favour the abolition of the penalty. It resolved the constitutionality of the penalty by interpreting literally the constitutional qualification of the right to life.

This article aims to show that even within this conservativism, the Supreme Court in the above cases could have found within the Constitution restrictions on the use of the penalty which, when effectively applied, will instigate a departure from the indiscriminate manner that the death penalty is being utilised in Nigeria and limit its application to extreme cases, if at all. The logic of the article, simply stated, is that the constitutionality of the death penalty may be constructed in a manner that makes its use consistent with international guidelines that reserve the penalty for the most serious crimes - that is, in countries that have not abolished the penalty. This requirement is contained in General Comment 3 on Article 4 of African Charter on Human and Peoples' Rights of the African Commission on Human and Peoples' Rights (African Commission) ${ }^{5}$ and the Principles and Guidelines on the Right to a Fair Trial and Legal Assistance in Africa.

(2011) LPELR-SC.283/2009.

5 General Comment 3 on the African Charter on Human and Peoples' Rights: The right to life (art 4). The General Comment was developed by the African Commission on Human and Peoples' Rights as an authoritative statement on the meaning and scope of the right to life under the African Charter. 


\section{The conundrums of $S v$ Kalu's legacy}

There have been several judicial and legislative developments since Kalu was decided: on the one hand, lawsuits that have attempted to relitigate the constitutionality of the death penalty, some of which floundered on the authority of Kalu. In one example, Joseph Amoshima $v$ The State, ${ }^{6}$ the appellant, relying on the separation of powers, sought a review of the constitutionality of the death penalty. The Supreme Court did not regard the challenge as anything novel. Relying on Kalu, the Court simply noted that the penalty 'is firmly entrenched in [Nigerian] law ...' Following Kalu and several other judicial pronouncements, ${ }^{7}$ courts routinely impose the death penalty and rule themselves as being without a discretion to alter sentences when the penalty is mandatory. ${ }^{8}$

On the other hand, a disturbing number of statutes prescribe the death penalty in Nigeria. Some of these make the penalty mandatory. ${ }^{9}$ Examples include the Robbery and Firearms (Special Provisions) Act, ${ }^{10}$ arguably the most notorious of all the death penalty laws. Section 1(2) of the Act prescribes the mandatory death penalty for robbing with an offensive weapon. Several death sentences have been imposed under this mandatory law. In the last decade or two, more capital offences have been created. In February 2017 Lagos State became the eighth state to make kidnapping a capital offence. In 12 northern states that enforce Shari'a criminal law, sexual offences have become punishable by death. ${ }^{11}$ The Terrorism Prevention Act 2011 as amended also reserves the penalty for serious terror-related offences. $^{12}$

Mandatory penalties are fraught with problems. For one, they lack an internal scheme for differentiating offences of varying levels of gravity and culpability. Second, they violate the separation of powers. Third, they deprive courts of discretion in sentencing, making it practically impossible to fit the punishment with the crime. A few examples under the Robbery and Firearms Act help to illustrate these

6 (2011) LPELR-SC.283/2009.

$7 \quad$ See Adeniji v State (2000) 645 NWLR 356; Okoro v State (1998) 14 NWLR 584; Akinyemi v State (1999) 6 NWLR 465.

8 See Tanko $v$ The State (2009) 1-2 SC (Pt 1) 198

9 See Death Penalty Database: Nigeria by Cornell Centre on the Death Penalty Worldwide www.deathpenaltyworldwide.org/country-search-post.cfm?country= Nigeria (accessed 21 October 2017).

10 Ch R11, Laws of the Federation of Nigeria 2004.

$11 \mathrm{n}$ 7. The states where kidnapping is a capital offence include Abia, Akwa lbom, Anambra, Ebonyi, Edo, Enugu, Imo and Lagos states. See https:// lagosstate.gov.ng/blog/2017/02/01/ambode-okays-death-penalty-for-kidnappers/ (accessed 21 October 2017). States that enforce Shari'a criminal law include Bauchi, Borno, Gombe, Jigawa, Kaduna, Kano, Katsina, kebbi, Niger, Sokoto, Yobe and Zamfara.

12 See Terrorism (Prevention) Act 2011; Terrorism (Prevention) (Amendment) Act 2013. 
problems. In the Amoshima case, ${ }^{13}$ the appellant was sentenced to death for killing another during a robbery in which a firearm was used. Causing death during an armed robbery is an aggravating feature that places the crime among the worst types of crime for which the death penalty would most certainly be considered. Under the Act, however, the offender need not cause death to be liable to the death penalty. Being in possession of a firearm or offensive weapon during a robbery is a sufficiently aggravating element. Thus, in Francis Odili $v$ The State ${ }^{14}$ the appellant was sentenced to death although the victims were only lacerated. No lives were lost and the victims subsequently recovered from their injuries. In Anthony Isibor $v$ The State ${ }^{15}$ the appellant received the death sentence for robbery at gunpoint, although no actual physical violence occurred. The common thread connecting these crimes was the involvement of a lethal weapon. Beyond that, the corpus delicti and injuries varied considerably.

The indiscriminate imposition of the death penalty in the above cases suggests that the offenders were equally culpable, regardless of the presence or absence of injury or harm to the victims. This cannot be further from apt. As far as moral culpability goes, the crimes in the Amoshima and Anthony Isibor cases are hardly on the same pedestal. The one caused death while the other only brandished a gun without causing physical harm. Nevertheless, both suffered the same legal consequences because a mandatory death penalty law proscribes their conduct. For the sentient judge this ought to raise genuine concerns about penal proportionality - concerns with a constitutional basis. Mandatory penal prescripts rob courts of the discretion to make judgment calls on how blameworthiness should impact the severity of the sentence. The stark unfairness of such laws confronted the court in Umoh Ekpo $v$ The State, ${ }^{16}$ where the court said that it felt compelled to impose the death penalty despite observing that the sentence was disproportionate to the crime. The offender in this case - also a robbery case - was a relatively young offender. The element of aggravation was a pair of pliers, which the court found not to be inherently lethal.

These examples demonstrate how statutory punishments can run afoul of the important principle of individualising punishment through measures that reinforce penal proportionality. Underlying the Robbery and Firearms Act is a legislative presumption that all armed robberies are the same, and the perpetrators equally culpable and liable. Unfortunately, Nigerian courts have upheld this presumption. Underlying their compliance with the mandatory penal prescripts is the view that once a law has been duly enacted by parliament which

13 Amoshima (n 6).

14 (1977) ANLR 49.

15 (2002) 2 SC (Pt II) 110.

16 LER [2014] CA/L/96/11. The value of the stolen items was N17 210 (US \$47,77). 
prescribes a penalty, courts are duty-bound to enforce the penalty. This view precludes a judicial evaluation of the constitutionality or proportionality of statutory penal prescripts.

Applying the death penalty to every instance of armed robbery, regardless of culpability, is hardly conscionable. However, Nigerian courts do so unquestioningly, exposing a dogmatic - if not flawed understanding of the separation of powers principle. In the Amoshima case, which was decided in 2014, the Supreme Court rejected a separation of powers argument that mandatory death penalty laws are an example of legislative overreach as they fetter judicial discretion. Citing its earlier decision in Tanko $v$ The State that trial courts lacked the competence to exercise discretion where the only prescribed sentence is death, the Court held: ${ }^{17}$

The law is settled that the use of the word 'shall' in an enactment $\ldots$ is usually interpreted to mean a mandatory provision which must be obeyed ... It is also settled law that where a statute prescribes a mandatory sentence ... the courts are without jurisdiction to impose anything less than the mandatory sentence as no discretion exists to be exercised in the matter. It is a duty imposed by law.

Consistent with this rather conservatively restrictive view of the doctrine of separation of powers, Nigerian courts generally do not subject statutory penalties to judicial review. In South Africa and Malawi, statutorily mandatory penalties have been held to invade judicial autonomy and deny offenders their fair trial rights. Where the penalties are grossly disproportionate, they have been held to violate human dignity. ${ }^{18}$ Disproportionate sentences raise germane questions about the fairness of the criminal justice system. In the Kalu case, the question pertained to the relationship between human dignity and punishment. In the Amoshima case, it concerned the limits of legislative power to prescribe penalties and the autonomy of judges to allocate sentences. Unfortunately, neither case resolved these questions.

\section{Punishment and the constitutional protection of human dignity in Nigeria}

Central to the Kalu appeal was the meaning of the rights to life and human dignity under the Nigerian Constitution of $1979,{ }^{19}$ but the real battle raged over later. Section 31(1)(a) of the Constitution entitled each individual to respect for the dignity of his or her person, prohibiting torture or inhuman and degrading treatment. The 1979 Constitution was subsequently replaced by the 1999 Constitution, 20

Amoshima (n 4) 12.

See sec 9.

Constitution of the Federal Republic of Nigeria, 1979.

Constitution of the Federal Republic of Nigeria, 1999. 
which contains a similar human dignity provision. The right to life provisions in both Constitutions (sections 30(1) and 33(1) respectively) are also in pari materia. These sections affirm the right, but grant that life may be taken pursuant to a criminal conviction.

Prior to the 1979 Constitution, Nigeria had two successive Constitutions. The first, the independence Constitution of 1960,21 guaranteed the right to human dignity in section 18(1), namely, that '[n]o person shall be subjected to torture or to inhuman or degrading punishment or other treatment'. That Constitution was replaced in 1963 by a Republican Constitution.22 Section 19(1) thereof reproduced section 18(1) of the 1960 Constitution word for word. Falling within the scope of prohibited acts under both provisions were acts of torture, or 'punishments' or 'other treatments' that met the 'inhuman' or 'degrading' epithets. In the 1979 Constitution, however, the human dignity clause took on a different phrase. 'Punishment' was removed from the clause so that it now reads as follows: 'Everyone is entitled to respect for the dignity of his person, and accordingly, no person shall be subjected to torture or to inhuman or degrading treatment.'

The reason for this textual change to the human dignity provision is not known, ${ }^{23}$ but if the socio-political context of Nigeria in the late 1980 s and 1990s had anything to do with it, then it may be suggested, anecdotally, that the character of the military administrations that decreed the Constitutions influenced the limited scope of the provision. The administrations were well-known for egregious human rights violations; the reckless disregard for human life and dignity; contempt for the rule of law; the repression of constitutional order; the ouster of judicial oversight; and a severe regime of punishment. It is in sync with the character of the administration that the Robbery and Firearms Act, for instance, with its severe penal prescripts, was enacted during military rule. ${ }^{24}$ Similar influences were brought to bear on transitions to civil rule that were initiated by the military. One author wrote that the transitions had the 'abiding paradox of ... [being] implemented under severe repression of civil society'. ${ }^{25}$ The culture of repression permeated law making during military rule and continued to shadow the Constitutions that were the products of military rule. ${ }^{26}$

\footnotetext{
21 Constitution of the Federation of Nigeria, 1960.

22 Constitution of the Federal Republic of Nigeria, 1963.

23 The author has not come across resources that discuss the change and the reasons for it.

24 See DO Aihe 'Fundamental human rights and the military regime in Nigeria: What did the courts say' (1971) 15 Journal of African Law 213.

25 CA Odinkalu 'The management of transition to civil rule by the military in Nigeria (1996-1996)' in K Amuwo, DC Bach \& Y Lebeau (eds) Nigeria during the Abacha years (1993-1998) (2001) 57.

26 How the culture impacts crime and punishment in post-transition Nigeria's will be a subject deserving of a study.
} 


\section{Textual and contextual interpretation of constitutional provisions}

In constitutional interpretation, words assume meanings that are best deciphered by reference to the history and context of the document. When provisions that define or curtail human rights become the subject of constitutional interpretation, text and context assume even greater significance. South African courts have often asserted this principle, with the South African Constitutional Court in $S v$ Makwanyane \& Another ${ }^{27}$ being a classic example. The Court's jurisprudence on the constitutionality of the death penalty is highly celebrated by death penalty abolitionists and was consulted by the Nigerian Supreme Court in the Kalu case.

In Makwanyane, the socio-political context that gave birth to the South African Constitution became relevant to resolving whether the death penalty was constitutional or violated the rights to life and human dignity. In the view of the Constitutional Court, South Africa's socio-political context lends meaning to words of the Constitution and Bill of Rights. ${ }^{28}$ As a document, the Constitution encapsulates the experiences, hopes and aspirations of the people, offering a framework that would guide South Africa away from a history of repression to embrace the new society that is based on a new culture of respect for human life and dignity, for the values embedded in the Constitution. ${ }^{29}$ The South African Constitution is the outcome of a widely consultative process.

Makwanyane made a compelling point: To not imbue the interpretation of the Constitution or Bill of Rights with the historical and socio-political context is to overlook the political rationality that underpins the Constitution, and to lose the meaning and purpose of its provisions. Nigeria experienced its own years of brutal repression under military rule, but the processes leading to the adoption of the 1979 and the 1999 Constitutions were not consultative. Thus, what is enshrined in the Nigerian Constitution as founding values were never negotiated through democratic consultative processes, but transformed into lex by military fiat. Nigerians were not given an opportunity to have the society of their aspirations defined in both Constitutions. Doctored and decreed by military regimes, and with many non-justiciable rights, the Constitutions were hardly progressive, neither were the processes that gave birth to them democratic. ${ }^{30}$

27 (CCT3/85) [1995] ZACC 3.

28 Corresponding to Ch IV of Nigeria's 1979 and 1999 Constitutions.

29 Makwanyane (n 27) paras 8-10 \& 218-224.

30 See FT Abioye 'Constitution-making, legitimacy and the rule of law: A comparative analysis' (2011) 44 Comparative and International Law Journal of Southern Africa 59; A Oladiran 'Democratising and legitimising constitution making in Nigeria: A focus on the 1999 Constitution of Nigeria' (2014) 4 International Journal of Humanities and Social Science 205. 
Nigerian courts also recognise the importance of context in constitutional interpretation. In Kalu, the Supreme Court made reference to the way in which the South African Constitutional Court engaged with that context in the Makwanyane case. Of course, necessary distinctions must be drawn between Makwanyane and Kalu. Makwanyane concluded that the death penalty violated the right to life because section 9 of the 1993 Constitution of the Republic of South Africa (interim Constitution) ${ }^{31}$ guaranteed an absolute right to life. Since section 9 did not recognise an exception to the right, the Constitutional Court was correct to conclude that the right was nonderogable. In Kalu the Nigerian Supreme Court came to a different conclusion based on the differently-worded right to life provision in the 1979 Constitution. Although section 30(1) of that Constitution guaranteed the right to life, it allowed judicial executions. Based on this provision, the Supreme Court rightly concluded that the right to life was not absolute in Nigeria. It was derogable.

Whereas text and context came to bear on interpretation in the Makwanyane case, Kalu was decided on the basis of a literal interpretation of a differently-worded protection of the right to life under the 1979 Constitution. However, even if the Supreme Court had taken context into consideration, its conclusion in Kalu could not have been different because the provision of the Constitution regarding the qualified nature of the right to life was quite lucid. This provision has been retained in the 1999 Constitution. What becomes rather befuddling with the Kalu case, however, is why the Supreme Court failed to notice that the provisions regarding human dignity in the Nigerian and South African Constitutions were textually different. As will be shown below, the Supreme Court could have come to a different conclusion had it recognised this difference.

Juxtaposing the human dignity clauses highlights the differences. Section 31(1)(a) of the 1979 Constitution provided: ${ }^{32}$

Every individual is entitled to respect for the dignity of his person, and accordingly -

(a) no person shall be subjected to torture or to inhuman or degrading treatment.

Section 10 of South Africa's interim Constitution assured to individuals 'respect for and protection of [their] dignity'. ${ }^{33}$ This provision essentially proclaimed a positive right to which individuals may lay a claim. A corresponding negative right is expressed in prohibitions against certain descriptions of punishment in section 11(2): 'No person shall be subjected to torture of any kind, whether physical,

31200 of 1993 . The interim Constitution was subsequently repealed by the Constitution of the Republic of South Africa, 1996. Sec 9 of the interim Constitution is now sec 11 in the 1996 Constitution.

32 The provision has been retained in sec 34(1)(a) of the 1999 Constitution.

33 Currently sec 10 of the 1996 Constitution. 
mental or emotional, nor shall any person be subjected to cruel, inhuman or degrading treatment or punishment'. 34

In other constitutions, the positive and corresponding negative rights are dealt with in the same section. For example, the Namibian and Zimbabwean Constitutions affirm human dignity and prohibit certain forms of punishment or treatment in single provisions. Similarly, section 54 of the Constitution of Hungary affirms human dignity while also enlisting prohibitions. ${ }^{35}$

The Constitutional Court's approach in Makwanyane was to read section 11(2) together with other rights, namely, the right to equality before the law and to equal protection of the law in section 8; the right to life in section 9 and human dignity in section 10; and to hold that the rights are consistent with human dignity. In other words, 'punishment must meet the requirements of sections 8,9 and 10, and this was so whether [the] sections are treated as giving meaning to section 11(2) or as prescribing separate and independent standards with which all punishments must comply'. ${ }^{36}$ An important principle of interpretation underlying this approach sets the interpretation of section 11(2) within the history and context of the Constitution's adoption. In the Court's view, the interpretation of the provision must aim to secure to 'individuals the full measure' of protection intended by the provision.

In sum, underpinning all rights guaranteed by the Bill of Rights is a basic consideration for human dignity, a consideration that draws deep on South Africa's experience with inequality under apartheid, which also impacted matters of punishment. Accordingly, sections 8, 9, 10 and 11(2) all impacted the constitutionality of the death penalty under South African law. The right to life, equality and respect for human dignity cannot give full protection if their interpretation and application are isolated from section 11(2).

There is a not so subtle textual difference in the constitutional provisions mentioned above and the human dignity clause in section 31(1)(a) of Nigeria's 1979 Constitution. The main distinguishing factor is the omission of the word 'punishment' from the prohibition of 'torture' and 'inhuman or degrading treatment' by section $31(1)(a)$. Could this mean that prohibitions of inhuman or degrading

34 Now sec 12(1)(e) (my emphasis).

35 The Constitutional Court referred to these provisions in the Makwanyane case. Art $8(1)$ of the Constitution of the Republic of Namibia provides that ' $[t]$ he dignity of all persons shall be inviolable'. Subsec (2)(b) provides that '[n]o persons shall be subject to torture or to cruel, inhuman or degrading treatment or punishment. Sec 15(1) of the 1980 Constitution of Zimbabwe provided that '[n]o person shall be subjected to torture or to inhuman or degrading punishment or other such treatment.' Sec 54 of the Constitution of Hungary provides that '... everyone has the inherent right to life and human dignity ... no one shall be subjected to torture or to cruel, inhuman or degrading punishment'. 
punishments are excluded in section 31(1)(a)? How fatal could such an exclusion be? The discussion below explores these questions.

\section{Interpreting 'cruel, inhuman or degrading treatment or punishment'}

In an apparent departure from prior Constitutions, the 1979 and 1999 Nigerian Constitutions omit punishment from the list of prohibited acts that offend human dignity. Does the omission alter the scope of the intended human protections in the prior Constitutions? Does section $31(1)(a)$ of the 1979 Constitution (section 34(1)(a) of the 1999 Constitution) as currently framed prohibit inhuman or degrading punishment? The section bears repeating:

Every individual is entitled to respect for the dignity of his person, and accordingly

(a) no person shall be subjected to torture or to inhuman or degrading treatment.

Current interpretations of the provision presume the elasticity of 'treatment' by importing criminal punishment into 'treatment'. According to these interpretations, therefore, section 31(1)(a) (now section 34(1)(a) in the 1999 Constitution) also prohibits inhuman or degrading punishment. A doctoral thesis ${ }^{37}$ that examined the issue relied on the definition of torture in article 1 of the International Convention Against Torture and Other Cruel, Inhuman or Degrading Treatment or Punishment (CAT) to suggest that 'treatment' in section $34(1)(a)$ of the 1999 Nigerian Constitution meant 'punishment'. ${ }^{38}$

This clearly is a wrong presumption, a conflation - rather than an interpretation - of two conceptually distinguishable words. It is a spontaneous and cognitively weak reaction to a lacuna in the Nigerian Constitution: It suggests that if the Constitution does not expressly prohibit 'inhuman or degrading punishment', an intention to do so must be presumed in the phrase 'torture or ... inhuman or degrading treatment'. After all, it is almost unthinkable that a constitution will fail to prohibit criminal punishments that are inhuman.

In Ozoukwu v Ezeonu II, ${ }^{39}$ the Nigerian Court of Appeal attempted a definition of section $31(1)(1)$ of the 1979 Constitution, looking at the

37 LI Uzoukwu 'Constitutionalism, human rights and the judiciary in Nigeria' unpublished PhD thesis, University of South Africa, 2010 95-104.

38 Uzoukwu (n 37). The thesis presumes that 'torture', 'cruel', 'inhuman' and 'degrading treatment or punishment' in art 1 applies to judicial punishment. This is misleading because art 1 of CAT excludes 'pain or suffering arising only from, inherent in or incidental to lawful sanctions' from the meaning of torture. 
key words - dignity, degrade, torture, inhuman treatment severally. ${ }^{40}$ Unfortunately the definition did not explain how its interpretation applied to judicial punishment. Nevertheless, the abovementioned thesis relied on the Ozoukwu definition to suggest that judicial punishment that is unduly excessive in length or severity, or disproportionate having regard to the seriousness of the offence, may amount to torture. Article 1 of CAT hardly lends itself to such interpretation. If anything, it excludes judicial punishment from the scope of CAT. 41

Interpretations that substitute 'treatment' for 'punishment' conflate distinguishable concepts. Dealing with whether the death penalty violated human dignity in the Makwanyane case, the Constitutional Court sought guidance from precedents in textual interpretation, and in the principle laid out in Minister of Home Affairs and the Minister of Education (Appeal No 4 of 1978) v Collins MacDonald Fisher and Eunice Carmeta Fisher, ${ }^{42}$ where the Privy Council ruled:

Respect must be paid to the language which has been used and to the traditions and usages which have given meaning to that language. It is quite consistent with this, and with the recognition that rules of interpretation may apply, to take as a point of departure for the process of interpretation a recognition of the character and origin of the instrument, and to be guided by the principle of giving full recognition and effect to those fundamental rights and freedoms with a statement of which the Constitution commences.

The Constitutional Court meticulously followed these principles in Makwanyane, differentiating the language of comparable human dignity clauses, but also drawing deep on South Africa's history and political experience to identify the underlying purposes of the South African Constitution and Bill of Rights. The textual similarities that the Court observed between section 11(2) of South Africa's interim Constitution and the Eighth Amendment to the Constitution of the United States - which prohibits 'cruel and unusual punishment' bolstered the court as it dug deep into American jurisprudence on cruel and unusual punishments. In the end the Court found, as has been found by the US Supreme Court, that disproportionately excessive punishments violate the prohibition of cruel, inhuman and degrading punishment in section 11(2).

The Constitutional Court also consulted other jurisprudence, notably Zimbabwean and Namibian case law. Section 15(1) of the

40 Ozoukwu v Ezeonu (n 39), per Tobi JCA, as he then was, attempted to define the key words of the provision. However, the provision is not helpful as it does not explain how the words apply to criminal punishment.

41 The thesis cites authorities to show that punishment that offends sensibilities in a modern society, or is discriminatory or selectively enforced offends human dignity. That may well be, but CAT hardly is the normative basis for impugning such punishment. Besides, the inhuman prison conditions under which a judicial sentence is served must be differentiated from judicial sentences as they do not necessarily render the sentence unconstitutional. 
1980 Constitution of Zimbabwe guarantees that '[n]o person shall be subjected to torture or to inhuman or degrading punishment or such other treatment'. Section $8(2)$ (b) of the Constitution of the Republic of Namibia is similar: 'No persons shall be subject to torture or to cruel, inhuman or degrading treatment or punishment.' In all of the above Constitutions, the reference to punishment is explicit.

The Zimbabwean and Namibian provisions came under judicial interpretation by the highest courts in both jurisdictions. The approach of the Supreme Court of Zimbabwe in $S v N c u b e^{43}$ construed torture, inhuman or degrading punishment or such other treatment disjunctively, finding that section 15(1) of the Constitution of Zimbabwe 'places prohibitions against (i) torture; (ii) inhuman punishment; (iii) degrading punishment; (iv) inhuman treatment; and (v) degrading treatment' severally. Although the Court was careful to recognise that the circumstances under which an imposed sentence is served could come up for evaluation under 'treatment' in section 15(1), the import was nevertheless clear that the focus of 'punishment' in section 15(1) is judicial punishment. A judicial pronouncement of punishment must not be inhuman or degrading in its character so as to violate human dignity. The treatment that is meted out to a convicted offender while serving a judicial sentence is altogether a separate matter. In the Court's very unambiguous words, 'treatment has a different connotation from punishment'. ${ }^{44}$

The Namibian Supreme Court also followed a disjunctive approach in Ex Parte Attorney-General: In Re Corporal Punishment by Organs of State. ${ }^{45}$ According to the Court:

It seems clear that the words ... [torture or ... cruel, inhuman or degrading treatment or punishment] have to be read disjunctively. Thus read, the section [8(2)(b) of the Constitution of Namibia] seeks to protect citizens from seven different conditions [namely]: (a) torture; (b) cruel treatment; (c) cruel punishment; (d) inhuman treatment; (e) inhuman punishment; (f) degrading treatment; [and] (g) degrading punishment.

Basically, the concepts of treatment and punishment must be differentiated.

The Zimbabwean and Namibian precedents guided the South African Constitutional Court in $S v$ Williams, ${ }^{46}$ where deliberations pivoted to international jurisprudence on the subject. First, the Court found that jurisprudence associated prohibitions of cruel, inhuman or degrading treatment with prohibitions of torture. Second, the Court also resorted to definitions propounded by the European Commission on Human Rights, which described 'inhuman treatment' as treatment that 'causes severe suffering, mental or physical, which in the particular situation is unjustifiable', and viewed torture as 'an

43 See S v Ncube, S v Ntshuma, Sv Ndhlovu 1988 (2) SA 702 (ZS) 715C-D.

44 As above.

$451991 \mathrm{Nr} 178$ (Sc) 187 paras G-H.

461995 (3) SA 632639 paras A-E \& 640 para J-641 para D. 
aggravated form of inhuman treatment'. To find a proper construction for 'inhuman or degrading punishments', however, the Court referred to the European Court's decision in Tryer $v$ The United Kingdom, ${ }^{47}$ where punishment was viewed as a judicial sentence or the immediate consequence thereof. These decisions, it must be said, are consistent with article 1 of CAT, which excludes 'pain or suffering arising only from, inherent in or incidental to lawful sanctions'.

The Nigerian Supreme Court's approach to interpreting section 31(1)(a) in Kalu was clearly not disjunctive. Apparently the Court's pronouncements and the legal arguments that were placed before it either did not pay attention to differences in the text of section $31(1)(a)$ and the various other human dignity provisions that were considered in the case, or they simply presumed that the text meant the same thing, thereby inadvertently foreclosing careful attention to the nuances that attend interpretations of foreign texts.

It may be useful to outline the various positions canvassed in Kalu as summarised by the Supreme Court. Arguing for the unconstitutionality of the death penalty, the appellant contended that the 'penalty as provided for in section 319(1) of the Criminal Code of Lagos State is inconsistent with ... section 31(1)(a), which expressly prohibit all forms of punishment that amount to torture, inhuman or degrading punishment'. ${ }^{48}$ The appellant's inference of an express prohibition of inhuman or degrading punishment in section 31(1)(a) can be misleading, for nowhere in the provision is punishment mentioned. Apparently, the rebuttable presumption here is that 'treatment' equals 'punishment'. 49

The gist of the submission by the state (respondent) was simple: The death penalty was provided for in the Constitution. Therefore, it cannot be intrinsically assailed or censured on account of the method of execution. The penalty and the method of execution are to be distinguished, presupposing that under Nigerian law only the method can be open to a constitutionality review. However, if the method of execution was objectionable, it may only be corrected by legislative amendment.

Like those of the respondent, the amicus briefs acknowledged that the right to life was not absolute under the Nigerian Constitution and that the preservation of the death penalty by the Constitution made it inconceivable that it would violate human dignity. It was thus not a contradiction that the Constitution protected the right to life and human dignity and at the same time allowed judicial execution. Only a constitutional amendment could change that. Until then, the death

47 (1978) 2 ECHR 1

48 Kalu (n 1) (my emphasis).

49 The appellant made a more tenable case when he linked the death row phenomenon with torture, inhuman and degrading treatment. However, the phenomenon, on its own, does not impact the constitutionality of a judicial sentence of death. The Court correctly rejected the argument. 
penalty cannot be ruled as unconstitutional, or as torture, inhuman or degrading treatment.

These arguments demonstrate how the Supreme Court could have been led into conflating punishment with treatment. However, the Court could also have noticed the error on its own. Unfortunately, it did not: After consulting various foreign authorities, the Court concluded: '[T]he opinion that the death penalty amounts to torture, inhuman and degrading treatment and therefore, intrinsically unconstitutional seems ... a minority view. ${ }^{50}$

The Supreme Court extended its error of conflation into presuming textual similarity in section 17(1) of the Jamaican Constitution, which prohibits 'torture or ... inhuman or degrading punishment or other treatment'. However, the provisions cannot be more different: While section 17(1) expressly refers to 'punishment', this word is missing in the corresponding provision of the Nigerian Constitution. The difference is substantial, and the Supreme Court's failure to notice or acknowledge it diminishes the conclusiveness of its pronouncements on the death penalty and human dignity. While the Court may yet have found, as it rightly did, that the death penalty does not violate human dignity per se, its reasoning could have been more nuanced, and the finding itself qualified. In jurisdictions that have upheld the constitutionality of the death penalty, not every decision to impose the penalty is necessarily constitutional. In the United States of America and Malawi, for example, punishments that are grossly disproportionate to the crime have been held to be cruel or unusual, or inhuman or degrading, failing to pass the test of constitutionality. South African courts also uphold this principle, although not necessarily in connection with the death penalty.

As it is, the Supreme Court's findings in Kalu render the nature of protections guaranteed by section 31(1)(a) (now section 34(1)(a) in the 1999 Constitution) far from clear. It is not safe to presume that the human dignity provisions of the 1979 and 1999 Constitutions retain the same scope and meaning as the corresponding provisions in the 1960 and 1963 Constitutions. ${ }^{51}$ The omission of 'punishment' in the later Constitutions is significant, potentially leaving these Constitutions ineffectual against punishments that are grossly disproportionate and in probable violation of human dignity in Nigeria.

50 Kalu (n 1) (my emphasis).

51 The author could not find judicial decisions or scholarly works from Nigeria on the subject. 


\section{Between human dignity and punishment: The proportionality test in a rights-based approach to sentencing}

In Furman $v$ Georgia ${ }^{52}$ and Gregg $v$ Georgia, ${ }^{53}$ the United States Supreme Court reckoned that the preservation of human dignity underlies prohibitions against 'cruel and unusual punishments' under the United States Constitution. At issue in both cases was whether the death penalty violated the Eighth ${ }^{54}$ and Fourteenth ${ }^{55}$ Amendments of the US Constitution. In Gregg $v$ Georgia, particularly, the Court adopted the view, relying on Furman $v$ Georgia and many of its other decisions, that the recognition of the death penalty by the Fourteenth Amendment meant that the penalty was neither invariably in violation of the Constitution, 56 nor ipso facto a 'cruel and unusual punishment' within the meaning ascribed to those words by the Eight Amendment.

For punishment to violate the Eight Amendment, it must violate 'the constitutional concept of cruelty', 57 such as where the means of executing it employs 'unnecessary and wanton infliction of pain', or the punishment was 'grossly out of proportion to the severity of the crime'. ${ }^{58}$ The Gregg case affirmed the principle that 'the punishment [of death in this case] is disproportionate in relation to the crime for which it is imposed'. As such, the Court has held the death penalty to be in violation of the Eighth Amendment when it was imposed for rape, and that imposing the penalty for such a non-lethal crime was grossly disproportionate and contrary to the due process guarantees of the Fourteenth Amendment. ${ }^{59}$ In the Furman case, the Court held that 'punishment may be degrading simply by reason of its enormity'.

The Constitutional Court consulted these American precedents in Makwanyane, when it articulated the proportionality test under South African law. In the Court's view, the proportionality test must be evaluated in light of constitutional protections against cruel, inhuman or degrading punishments. ${ }^{60}$ This approach rightly identifies punishment as a curtailment or limitation of rights that are

52408 US 238 (1972).

53428 US 153 (1976).

54 The Eighth Amendment provides that '[e]xcessive bail shall not be required, nor excessive fines imposed, nor cruel and unusual punishments inflicted'. See US Constitution online, http://www.usconstitution.net/const.html (accessed 21 October 2017).

55 Sec 1 of the Fourteenth Amendment provides that the state shall not deprive 'any person of life, liberty, or property, without due process of law'. See US Constitution online (n 54).

56 Gregg $v$ Georgia (n 53) 170.

57 Gregg $v$ Georgia 179.

58 Gregg $v$ Georgia 52 170-183, but see particularly 170, $179 \& 183$.

59 Coker $v$ Georgia 433 US 584 (1977).

60 Sec 11(2) of the interim Constitution, now sec 12(1)(e) of the 1996 Constitution. 
guaranteed - also to the offender - by the Constitution. Makwanyane resolved that section $33(1)$ of the interim Constitution ${ }^{61}$ required proportionality to be achieved between a crime and its punishment. Section 33(1) is the limitation clause of the Bill of Rights: It required that rights be limited only by law of general application 'to the extent that is reasonable and justifiable in an open and democratic society based on human dignity, equality and freedom, taking into account all relevant factors ...' The Constitutional Court viewed the provision as requiring a careful balancing of competing values in punishment that is, the interests of society and of the offender, and the gravity of the crime - in light of the Constitution's values. The balancing act made proportionality between crime and punishment a constitutional imperative. $^{62}$

Thus, a penal measure must be justifiable in a constitutional order, and consistent with the prevailing values of society. The means for achieving the penal objective must not restrict the right of the offender beyond what is reasonably justifiable, and must be necessary and reasonably connected with the achievement of the objective. The degree to which the offender's rights are restricted must be commensurate to the crime. In other words, the court must seek the least intrusive means available to it, if that meets the demands of justice. ${ }^{63}$ The Constitution requires courts to approach punishment with this outlook, taking proportionality into account as an ingredient for determining whether punishment is cruel, inhuman or degrading. A penalty that unreasonably offends these protections presumably would be grossly disproportionate. ${ }^{64}$

The Nigerian equivalent of section 33(1) is section 45(1) of the 1999 Constitution (section 41(1) of the 1979 Constitution). ${ }^{65}$ The texts are not similar, but like its South African equivalent, the Nigerian provision allows derogations from fundamental rights by laws that are 'reasonably justifiable in a democratic society', in the interests of defence, public safety, public order, public health, public morality and

61 Sec 36(1) of the 1996 Constitution.

62 According to the Constitutional Court, 'the limitation of constitutional rights ... involves the weighing up of competing values, and ultimately an assessment based on proportionality ... Proportionality calls for the balancing of different interests. In the balancing process, the relevant considerations are the right that is limited, and its importance to an open and democratic society based on freedom and equality; the purpose for which the right is limited and the importance of that purpose to such society; the extent of the limitation, its efficacy and particularly, where the limitation is necessary, whether the desired ends can reasonably be achieved through other means less damaging to the right in question. In the process, regard must be had to the provisions of section 33(1), and the underlying values of the Constitution ...'

63 See Makwanyane (n 27) paras 103-104.

64 Makwanyane para 94.

65 Sec 45 of the 1999 Constitution of the Federal Republic of Nigeria. 
to protect the rights and freedoms of other persons. ${ }^{66}$ The meaning of the provision has been elucidated in cases that challenge the violation of fundamental rights, ${ }^{67}$ but hardly in relation to statutorily prescribed penalties. In Kalu, the Supreme Court could have followed the Constitutional Court's lead in Makwanyane to resolve when the death penalty violated human dignity, but it did not. Had it done so, penal proportionality would have become a key issue, and the Court would have had to determine when the death penalty, although constitutionally permissible, would be grossly disproportionate and, therefore, unjustifiable. That, invariably, could also have turned the Court's attention to the very important question of separation of powers that emerged in the Amoshima case.

\section{The Amoshima case: Parliamentary overreach in legislating punishment}

According to section 36(12) of 1999 Constitution, punishments may only be imposed for crimes that are defined in written law, and for which penalties are also provided in written law. The provision enshrines the principle of legality in the Constitution, bringing it into the sphere of criminal law. However, section 45 of the 1999 Constitution (section 41 of the 1979 Constitution) establishes conditions that must be met by legislation that limit or derogate from the rights guaranteed by the Constitution. Such legislation must satisfy the test of reasonableness. In South African jurisprudence, the limitations clause imposes the reasonableness test on laws that prescribe criminal penalties. Nigerian courts generally also assert their power to review legislation or determine whether the exercise of legislative power conforms to the Constitution. ${ }^{68}$ In relation to statutory penalties, however, the courts have been disinclined to exercise judicial review.

In the Amoshima case ${ }^{69}$ the appellant requested the Supreme Court to review the constitutionality of the mandatory death penalty in section 1(2)(a) of the Robbery and Firearms (Special Provisions) Act (Act). The appellant's argument inter alia centred on the point that

66 The provision reads '[n]othing in sections 34, 35, 36, 37 and 38 of this Constitution shall invalidate any law that is reasonably justifiable in a democratic society (a) in the interest of defence, public safety, public order, public morality or public health; or (b) for the purpose of protecting the rights and freedom of other persons'.

67 Anzaku v Governor of Nassarawa State (2006) All FWLR (Pt 303) 308; Osawe v Registrar of Trade Unions (1985) 1 NWLR (Pt 4) 755; Medical and Dental Practitioners Disciplinary Committee $v$ Okwonkwo (2001) FWLR (Pt 44) 542; Chukwuma v COP (2008) 8 NWLR (Pt 927) 278; IGP v ANPP (2007) 18 NWLR (Pt 1066) 457.

68 See Independent Electoral Commission \& Another v Musa \& Others (2003) AHRLR 192 (NgSC 2003) (INEC case), where the Supreme Court annulled provisions of an Electoral Act.

Amoshima (n 6). 
the provision intruded on the constitutional powers of courts to adjudicate matters, thereby negating the principle of separation of powers enshrined in sections 4, 5 and 6 of the 1999 Constitution. In the appellant's view, the mandatory nature of the death penalty under the Act also trampled the constitutionally-derived powers of appellate courts to entertain appeals against death sentences which, in turn, violated the appellant's fair trial rights (namely, the right of appeal).

The limitations of legislation are key to comprehending the appellant's arguments. Generally, law makers aim to pass laws that are as comprehensive as possible, and will be guided by facts, circumstances and assumptions that they presume to be relevant to the subject matter. However, these are mutable, and not all the circumstances and changes can be foreseen. The language of legislation may also with time change in meaning. How these changes will impact human behaviour and law enforcement is often unpredictable. Law making shows sensitivity to these variables by seeking flexibility over avoidable rigidity, and in the recognition that regulatory authorities and courts will fill unanticipated gaps when they breathe life into otherwise insentient enactments. ${ }^{70}$

This is no less true for criminal statutes. Their inability to foresee or respond to the infinite and complicated 'variety of circumstances that attend the commission of crimes' has led some jurisdictions to prefer judicial discretion in sentencing over and above the rigid application of statutorily legislated penalties. This was clearly the attitude of the South African Supreme Court of Appeal in $S v$ Malgas, ${ }^{71}$ where the Court warned that applying statutory penalties indiscriminately would only create arbitrary and unfair consequences. Judicial discretion offers a rational alternative to such outcomes: Courts occupy a better position than legislatures to appraise the circumstances in which individual crimes are committed and to adapt sentences to meet the needs of justice in each case. ${ }^{72}$

Accordingly, South African courts assert that sentencing is 'preeminently a matter for the discretion of the trial court', ${ }^{73}$ and have vigorously resisted mandatory penalties because they fetter sentencing discretion. ${ }^{74}$ Judicial discretion is a sine qua non for individualising punishment, or for fitting punishment with the crime

70 See C Ilbert The mechanics of law making (1914) 109; Center on Law and Globalization 'How countries deal with incomplete law' https://clg.portalxm.com/ library/keytext.cfm?keytext_id=26 (accessed 3 November 2017).

712001 (1) SACR 469 (SCA).

72 Consistent with this view, South African courts have routinely resisted mandatory penalties.

73 Se $R$ v Mapumulo \& Other Appellants 1920 AD 56, where South Africa's Appellate Division reasoned that the trial court was in a better position to appreciate the case, evaluate the circumstances of the crime and decide the measure of punishment. See $R$ v Freedman 1921 AD 603; S v Rabie 1975 (4) SA 855 (A).

74 See D van Zyl Smit 'Sentencing and punishment' in SM Bishop \& J Brickhill (eds) Constitutional law of South Africa 2 ed Revision Service 4 (2012) 49-11 to 49-17. 
and offender. Discretion engenders a fair balancing of factors that speak to the justice of the matter. Mandatory penalties achieve the opposite; they strip courts of the ability to the exercise judgment. ${ }^{75}$ Of course, courts do not seek amorphous discretion, as that would engender contradictions or inconsistencies in sentencing. What they assert is a rational or structured utilisation of discretion, which permits courts to operate within a system of judicially and legislatively developed guidelines that ensure the judicious use of discretion.

Thus, when Amoshima challenged the Nigerian Supreme Court to determine whether the mandatory death penalty breached the separation of powers, it in fact was seeking a judicial determination regarding whether a court's discretion can be lawfully excluded in sentencing. However, closely associated with the separation of powers argument was whether an appellate court's powers to entertain appeals from death sentences - a power conferred by the Constitution - can be abrogated by statute. Stated differently, the second issue was whether a mandatory death penalty could abrogate the appellant's constitutional right of appeal against a death sentence, thereby infringing his right to a fair trial. These were substantial and relevant grounds for appeal, but the Court dismissed them as 'academic or hypothetical'. In its view, the fact that the appeal was being heard by the Court confirmed that the appellant was exercising his right of appeal. This rather tepid mischaracterisation of the substance and relevance of the appellant's arguments conflated the right to appeal a conviction with the right to appeal a sentence. These are two different things under the Nigerian Constitution. It will be useful to consider how the Supreme Court resolved the appeal.

\subsection{Resolving the separation of powers argument}

In the Amoshima case the Supreme Court had the following to say on the separation of powers and the mandatory death penalty:

[W] hereas it is the duty of the legislature to enact laws, that of the judiciary is to interpret the laws so made. The duty both to make and amend laws so made belongs exclusively, by Constitutional arrangement, to the legislature as provided under section 4 of the Constitution of the Federal Republic of Nigeria ... The death penalty may be said to be degrading of human beings, etc, but same cannot be said where the law recognises the existence and desires its enforcement by the law.

The Court held further:

It is settled law also that where a statute prescribes a mandatory sentence in clear terms as in the instant case, the courts are without jurisdiction to impose anything less than the mandatory sentence as no discretion exists to be exercised in the matter. It is a duty imposed by law.

These comments seem to suggest that courts cannot review how the legislature exercises its powers to enact a criminal statute. That is

75 S v Toms; S v Bruce 1990 (2) SA 802 (A) 806H-807A. 
hardly a correct interpretation of the doctrine of separation of powers. True, the authority of the legislature to enact laws is secured by the Constitution, but so is the court's authority to review whether the legislature has acted consistently with the Constitution. Section 4 of the 1999 Constitution, which defines the law-making powers of parliament, subjects that power to the jurisdiction of the courts. ${ }^{76}$ Therefore, the Supreme Court erred in the Amoshima case when it claimed that there can be no escape routes where statutorily mandated penalties are involved. ${ }^{77}$ The issue hardly concerned escape routes, but whether Parliament encroached judicial authority contrary to section 4(8) of the Constitution by mandating the death penalty.

In the South African case of The Executive Council of Western Cape \& Others $v$ The President of the Republic of South Africa \& Others ${ }^{78}$ the Constitutional Court, after reviewing several commonwealth decisions that recognised that legislative power must be exercised according to the Constitution, also noted the Privy Council's decisions in AttorneyGeneral for Australia $v$ the Queen ${ }^{79}$ and Liyanage $v$ The Queen, ${ }^{80}$ which annulled legislation that encroached judicial power. Similarly, in Godfrey Ngotho Mutiso $v$ The Republic, ${ }^{81}$ the Kenyan Court of Appeal held that a law that has the effect of 'tying the hands of the judiciary in executing its function to administer justice is inconsistent with the Constitution'. This finding rendered all Kenyan statutory provisions that prescribe a mandatory death sentence inconsistent with the Constitution and void.

There is no reason why a similar fate would not befall laws that make the death penalty mandatory for certain offences in Nigeria, such as the Robbery and Firearms Act and new kidnapping laws, and so forth. Section 4(8) of the 1999 Constitution gives Nigerian courts the power to subject such laws to constitutional review. Such a review may be done on a separation of powers ground, but it a may also be reasonableness review under section 45(1) of the Constitution. Unfortunately, it seems that judicial reviews of criminal statutes that prescribe mandatory penalties have not occurred in Nigeria. However, there is Malawian and South African jurisprudence on how the limitation clause applies to punishment, which places proportionality at the heart of resolving whether a penalty is a reasonable limitation of the offender's rights, having regard to his crime. Under South African jurisprudence, ${ }^{82}$ for example, it has been held that the penalty must be evaluated in the context of what is a 'reasonable and justifiable

76 Subsec (8).

77 Amoshima ( $n$ 6). Echoing the lead judgment, Fabiyi JSC held: '[W]here a mandatory sentence is provided ... same must be pronounced without reservation.'

78 [1995] ZACC 8.

79 (1957) 95 CLR 529.

80196710 AC 259.

81 [2010] eKLR.

82 Makwanyane (n 27); Williams (n 46). 
[limitation] in an open and democratic society that is based on human dignity, equality and freedom'. The evaluation must consider the nature of the right that is being limited, and the nature and extent of the limitation. Punishment could be disproportionate if it fails this test, and potentially cruel, inhuman or degrading. ${ }^{83}$ Malawi's jurisprudence on sentencing (considered below) is similar.

\subsection{When mandatory punishments violate access to justice rights}

The appellant in the Amoshima case further argued that his right to a fair hearing, the full measure of which he sought to exercise by appealing his death sentence, had been infringed by the mandatory death penalty. It was a crucial point of law that the Supreme Court, unfortunately, also did not comprehend. The right of appeal is one of a cluster of access to justice rights guaranteed to offenders by sections 36(4) and 46(1) of the 1999 Constitution. They include the right of access to court and the right to a fair trial. Sections $233(2)(d)$ and 241(1)(e) of the Constitution also bring within the cluster the right to approach an appellate court. These provisions affirm a convicted offender's right to appeal a death sentence. On the basis of the provisions, a death sentence imposed under the Robbery and Firearms Act ought to be appealable.

Together, the constitutional provisions raise the pertinent issue of whether Acts of Parliament can foreclose appeals against mandatory sentences. The corollary of the Supreme Court's decision in the Amoshima case is that such appeals cannot be entertained. In the Court's view, when the word 'shall' is used in an enactment, obedience becomes mandatory, as the word connotes an explicit and legally mandatory command. According to this interpretation, although an offender may appeal his conviction for armed robbery under the Robbery and Firearms Act, he cannot do so against the consequential mandatory sentence. If his conviction is upheld, the death sentence automatically follows. It cannot be varied.

The High Court of Malawi has followed a fundamentally different and correct - approach on the subject. In the Malawian locus classicus case of Kafantayeni \& Others $v$ Attorney-General, ${ }^{84}$ the High Court was faced with questions similar to those considered by the Nigerian Supreme Court in Amoshima. Like the Nigerian Constitution, the Malawian Constitution preserves the death penalty. However, the appellant in Kafantayeni argued, inter alia, that section 210 of the Malawi Penal Code, which made the death sentence mandatory for murder, violated the prohibition of cruel, inhuman or degrading treatment or punishment by section 19(3) of the Malawian

83 Makwanyane (n 27).

84 Unreported, Constitutional Case 12 of 2005; the case can be accessed on JSTOR or (2007) 46 International Legal Materials. 
Constitution. It also violated the right to fair trial under section $42(2)(f)$ by denying a discretion in sentencing. ${ }^{85}$

Having found that section 210 of the Penal $\operatorname{Code}^{86}$ made the death penalty mandatory for the offence of murder and excluded judicial discretion in sentencing, the High Court then considered whether the penalty was inhuman or degrading. It drew considerably on the decision in Reyes $v$ the Queen ${ }^{87}$ where the Privy Council censured the mandatory death penalty for all murders, as it deprived the defendant of a chance to show why sentence should be mitigated, or deprived the courts of 'any consideration of the detailed facts of the particular case or the personal history and circumstances of the offender'. The Court viewed the imposition of the death sentence under such mandatory requirements as inhuman and degrading, and potentially 'wholly disproportionate to the defendant's criminal culpability'. In support of this view, the Privy Council cited the views of the Court of Appeal for Saint Lucia and Saint Vincent and Grenadines in Newton Spence $v$ The Queen and Peter Hughes $v$ The Queen, ${ }^{88}$ where Byron $\mathrm{CJ}$ framed the issue as follows:

The issue here is whether it is inhuman to impose a sentence of death without considering mitigating circumstances of the commission of the offence and the offender; whether the dignity of humanity is ignored if this final and irrevocable sentence is imposed without the individual having any chance to mitigate; whether the lawful punishment of death should only be imposed after there is a judicial consideration of the mitigating factors relative to the offence itself and the offender.

Concurring, Saunders JA held: ${ }^{89}$

It is and has always been considered a vital precept of just penal laws that the punishment should fit the crime. If the death penalty is appropriate for the worst case of homicide, then it must surely be excessive punishment for the offender convicted of murder whose case is far removed from the worst case. It is my view that where punishment so excessive, so disproportionate must be imposed on such a person courts of law are justified in concluding that the law requiring the imposition of the same is inhuman. I am driven firmly to one conclusion. To the extent that the respective sections of the Criminal Codes of the two countries are interpreted as imposing the mandatory death penalty those sections are in violation of section 5 of the Constitution.

85 The appellant also contended that sec 210 of the Penal Code amounted to an arbitrary deprivation of life because the death penalty was mandatory without regard to the circumstances of the crime, and that it violated the constitutional principle of separation of powers. However, the Court resolved the case on the two issues of the right to fair trial and the prohibition of cruel, inhuman and degrading treatment or punishment.

86 The section provides that '[a]ny person convicted of murder shall be sentenced to death'.

87 [2002] 2AC 235.

88 Unreported, 2 April 2001 (Criminal Appeals 20 of 1998 and 14 of 1997) para 30. The cases were consolidated.

89 Spence and Hughes (n 88) para 216. 
Their Lordships' views interlaced protection for human dignity question with the right to fair trial in a manner that reinforces the interdependence of rights. Returning to the fair trial question in Kafantayeni, the Malawian High Court rightly concluded that a criminal trial does not terminate with a conviction but with sentencing. Thus, the fair trial rights that ensure due process at the pre-conviction phase of the trial also obligate compliance with due process at the sentencing phase. In the Court's words, 'the principle of "fair trial" requires fairness of the trial at all stages of the trial including sentencing'. 90

In the Court's correct view also, fair trial rights during sentencing are protected by article 14(5) of the International Covenant on Civil and Political Rights (ICCPR) to which Malawi is a signatory, just like Nigeria. According to this article, 'everyone convicted of a crime shall have the right to his conviction and sentence being reviewed by a higher tribunal according to law' ${ }^{91}$ By making the death penalty mandatory for murder, section 210 of Malawi's Penal Code precluded appeals against sentence, violating the right to a fair trial. The Court found support for this conclusion in the case of Edwards $v$ The Bahamas, ${ }^{92}$ where the Inter-American Commission on Human Rights held that the mandatory death sentence violated fair trial because it is compulsory, automatic and precludes an appeal.

A very pertinent view on the right of access to justice for offenders was articulated in Kafantayeni and deserves a brief mention here. This right is guaranteed by section 41(2) of the Malawian Constitution and assures to all the right of 'access to any court of law or any other tribunal with jurisdiction for final settlement of legal disputes'. The provision enshrines the right of access to trial and appellate courts. The Malawian High Court's views on this provision as it impacts the death penalty are compelling: ${ }^{93}$

We affirm that issues of sentencing are legal issues for judicial determination and are therefore within the purview of section 41(2) of the Constitution; and the mandatory death sentence under section 210 of the Penal Code, by denying a person convicted of murder the right of access on the sentence to the final court of appeal, is in violation of section 41(2) of the Constitution. In regard to the death penalty, which is the ultimate punishment any person can suffer for committing a crime. Irrevocable as it is once carried out, we would reject any notion that any restriction or limitation on the guarantee under section 41(2) of the Constitution of the right of access to a court of final settlement of legal issues, denying a person to be heard in mitigation of sentence by such court, can be justified under [section 44] of the Constitution as being reasonable or necessary in a democratic society or to be in accord with international human rights standards.

90 Kafantayeni (n 84).

91 My emphasis.

92 Inter-American Commission on Human Rights (7 March 2000) OEA/Ser L/V/II.106 Doc 3 rev 177.

93 Kafantayeni (n 84) 571. 
Section 44(1) of the Malawian Constitution is the equivalent of section 45(1) of the 1999 Nigerian Constitution.

\section{Sentencing under the Administration of Criminal Justice Act, 2015}

Among the interesting innovations of the new Administration of Criminal Justice Act are sections 310 and 311 of the Act which create a framework for sentencing hearings. These provisions allow criminal defendants to call witnesses (including expert witnesses), lead evidence and be cross-examined regarding factors that should mitigate sentence, while the prosecution may also tender evidence in aggravation. The provisions are a notable departure from previous sentencing law and practice in Nigeria, in which courts proceeded to sentence once a conviction had been reached, merely affording the defendant an opportunity for allocution before the sentence is pronounced. The allocution is not a sentencing hearing, as it only allows the defendant to plead for leniency. ${ }^{94}$

Allocutions are meaningless when the offence attracts a mandatory penalty. That said, it needs to be explored how mandatory penalties will be impacted by sections 310 and 311 of the Act. One interpretation, having regard to the obligatory language of the provisions and Part 1 of the Act, ${ }^{95}$ is that the Act overrides all other laws on criminal procedure. Thus, courts may be compelled to follow the requirements of sections 310 and 311 even where mandatory penalties apply. However, the more compelling interpretation would be that statutory penalties are not a matter of procedure, and that where a penalty is by law mandatory, it does away with the need for a sentencing hearing. The problem with this interpretation, however, is that it would perpetrate the constitutional breaches illustrated above. This makes challenging the constitutionality of mandatory punishments the only way to ensure a judicious consideration of relevant factors under section 311 of the Act.

\section{Conclusion}

Judicial pronouncements on the death penalty in Nigeria make one thing clear: If the death penalty were to be abolished, it will require constitutional amendment. Also requiring constitutional amendment is section 34 of the 1999 Constitution. As this article demonstrated,

94 IKE Oraegbunam 'Critical reflections on some procedural issues of prosecution of capital crimes in Nigeria' (unpublished) www.academia.edu (accessed 21 October 2017).

95 Part 1 identifies the general purpose of the Act to be the regulation of criminal procedure. It also commands courts and criminal justice administrators to comply with the Act. 
the provision is, at the least, ambivalent on inhuman and degrading punishments. However, constitutional amendments take time, and public attitudes on the death penalty may not in the foreseeable future favour the abolition of the death penalty. Meanwhile, the death penalty continues to be imposed, with more than 2200 inmates currently on death row, ${ }^{96}$ many of whom were sentenced under mandatory death penalty laws. In 2017 Nigeria imposed 621 death sentences, the highest globally. ${ }^{97}$

Even if Nigeria continues to retain the death penalty in the foreseeable future, its retention of the penalty must conform to regional and international principles applicable to death penalty retentionist countries. Particularly pertinent are the Principles and Guidelines on the Right to a Fair Trial and Legal Assistance in Africa, adopted by the African Commission, which states that retentionist states shall reserve the death sentence for the most serious crimes and in accordance with the principle of legality, and that persons sentenced to death have the right to appeal the sentence. States shall take steps to ensure that such appeals become mandatory, 98 and that in no circumstances shall the death penalty be mandatory.

The mandatory death penalty in Nigeria clearly is in conflict with these principles, and the increase in death penalty laws and death sentences raises pertinent concerns. The case ought to be made - if Nigeria remains a retentionist country for the foreseeable future - for a review of death penalty laws to ensure conformity with the principles. Unfortunately, however, law reform takes time in Nigeria, and criminal law making is not always predicated on a clear, consistent and holistic policy of reform. In one noteworthy development, in 2013, the National Assembly began to consider the Bill for an Act to Amend the Robbery and Firearms (Special Provisions) Act 2013, which proposed to restrict the death penalty to robberies that took human life. ${ }^{100}$ Curiously, however, while the Bill was

96 ARA Shaban 'Nigerian judge wants death row executions carried out to ease prison congestion' African News 2 February 2017, http://www.africanews.com/ 2017/02/02/nigerian-judge-wants-death-row-executions-carried-out-to-easeprison-congestion/ (accessed 21 October 2017).

97 Amnesty International 'Amnesty International Global Report: Death Sentences and Executions 2016' (2017) https://www.amnesty.org/download/Documents/ ACT5057402017ENGLISH.PDF (accessed 13 September 2018). See also Amnesty International 'The death penalty in 2017: Facts and figures' 12 April 2018, https:// www.amnesty.org/en/latest/news/2018/04/death-penalty-facts-and-figures-2017/ (accessed 13 September 2018).

98 African Commission on Human and Peoples' Rights 'Principles and Guidelines on the Right to a Fair Trial and Legal Assistance in Africa' http://www.achpr.org/ instruments/principles-guidelines-right-fair-trial (accessed 13 September 2018).

99 General Comment 3.

100 When the Bill is passed, life sentences will replace the death penalty where the crime involves no loss of life. The death penalty will be mandatory when homicide accompanies the robbery. This element may yet be challenged for excluding judges' discretion to individualise punishment based on an offender's culpability. 
pending, the National Assembly commenced deliberations on another Bill to make hate crimes capital offences. ${ }^{101}$

This makes Nigerian courts the arena for realising the African Commission's Fair Trial Principles and raising the bar on the use of the death penalty. They must, like their contemporaries in Kenya, Malawi, South Africa and the United States, begin to ask: When would punishments be so disproportionate as to be inhuman and degrading? There is a serious constitutional imperative to do so. Nigeria may well have several offenders who have been wrongly sentenced under mandatory death penalty laws such as the Robbery and Firearms Act. The constitutionality of these sentences is questionable on account of the fair trial rights that are infringed by such laws. It would be against the values of the democratic society that Nigeria aspires to be.

The first measure in redressing these constitutional violations would be to freeze executions by a judicial order until sentences passed under mandatory death penalty laws have been reviewed. The prospects for a fresh and successful challenge on the constitutionality of section 1(2) of the Robbery and Firearms Act and other mandatory death penalty laws are high. But more must follow, and Kafantayeni sets a precedent. Kafantayeni instigated a review process by which convicts who were mandatorily sentenced to death in Malawi underwent resentencing. The process did not render the death penalty redundant in Malawi. Rather, it was meant to ensure that punishments reflect the offender's moral culpability, and that death sentences are only used as a maximum sentence for the worst cases of homicide. $^{102}$ As a result, Malawi can boast an emerging and interesting resentencing jurisprudence.

Malawi is hardly the only country that has taken this path. In Spencer and Hughes, the Court took the correct view that according convicts their fair trial rights in a resentencing process meant taking the parties through sentencing hearings where they could offer evidence in mitigation and aggravation to assist the court to achieve a proportionate sentence: ${ }^{103}$

The offender should have an opportunity to mitigate on the same terms as he currently has to defend, that is he should have the right to remain silent, to make an unsworn statement (where substantive law allows the same) or to give evidence on oath and be liable to cross-examination. He must also be allowed to call witnesses on his behalf, and to address the jury himself or by his counsel. The prosecution should have the right to adduce

101 AA Ibrahim 'Death for hate speech: CDHR, others kick as senator defends Bill' https://punchng.com/death-for-hate-speech-chdr-others-kick-as-senator-defendsbill/ (accessed 13 September 2018); D Oyedele 'Hate penalty for hate speech' March 2018 https://www.thisdaylive.com/index.php/2018/0/11/hate-penalty-forhate-speech/amp/ (accessed 13 September 2018).

102 See E Gumboh 'Realising the promise of Kafatayeni: The emerging jurisprudence from the resentencing of death row inmates in Malawi' http://gavel.africanlii.org/ node/15 (accessed 13 September 2018).

103 Spence and Hughes (n 88) 23 para 58. 
evidence on the factors relevant to the decision to be taken and also to address. A verdict against imposition of the death penalty would require the judge to impose a sentence of imprisonment in the discretion of the trial judge.

It is important to observe that the Court in Hughes and Spencer was also mindful of the many inmates whose fate on death row would be impacted in one way or another by its decision. Nevertheless, the Court, speaking obiter, was persuaded that a sentence review was the constitutionally-imperative path to follow. The justice of the matter demanded a determination of whether their offences were of a capital or non-capital nature.

This is the path that Nigeria should take. Of course, this may require developing new standards for differentiating offence gravity for offences that have hitherto been liable to the death penalty. This would require considerable effort but is nevertheless the right thing to do, constitutionally. Due process demands that sentences that have been imposed under mandatory death penalty laws ought to be reviewed. A review will redress the constitutional violations foisted by such laws. It will insert human dignity and proportionality into sentencing in Nigeria. 